\title{
The Significance of the Variation Theory in Cross-Cultural Communication
}

\author{
YI WAN \\ Sichuan University of Science and Engineering
}

Follow this and additional works at: https://docs.lib.purdue.edu/clcweb

Part of the American Studies Commons, Comparative Literature Commons, Education Commons, European Languages and Societies Commons, Feminist, Gender, and Sexuality Studies Commons, Other Arts and Humanities Commons, Other Film and Media Studies Commons, Reading and Language Commons, Rhetoric and Composition Commons, Social and Behavioral Sciences Commons, Television Commons, and the Theatre and Performance Studies Commons

Dedicated to the dissemination of scholarly and professional information, Purdue University Press selects, develops, and distributes quality resources in several key subject areas for which its parent university is famous, including business, technology, health, veterinary medicine, and other selected disciplines in the humanities and sciences.

CLCWeb: Comparative Literature and Culture, the peer-reviewed, full-text, and open-access learned journal in the humanities and social sciences, publishes new scholarship following tenets of the discipline of comparative literature and the field of cultural studies designated as "comparative cultural studies." Publications in the journal are indexed in the Annual Bibliography of English Language and Literature (Chadwyck-Healey), the Arts and Humanities Citation Index (Thomson Reuters ISI), the Humanities Index (Wilson), Humanities International Complete (EBSCO), the International Bibliography of the Modern Language Association of America, and Scopus (Elsevier). The journal is affiliated with the Purdue University Press monograph series of Books in Comparative Cultural Studies. Contact: <clcweb@purdue.edu>

\section{Recommended Citation}

WAN, YI. "The Significance of the Variation Theory in Cross-Cultural Communication." CLCWeb: Comparative Literature and Culture 19.5 (2017): <https://doi.org/10.7771/1481-4374.3113>

This text has been double-blind peer reviewed by $2+1$ experts in the field.

The above text, published by Purdue University Press @Purdue University, has been downloaded 235 times as of $11 /$ $07 / 19$.

This document has been made available through Purdue e-Pubs, a service of the Purdue University Libraries. Please contact epubs@purdue.edu for additional information.

This is an Open Access journal. This means that it uses a funding model that does not charge readers or their institutions for access. Readers may freely read, download, copy, distribute, print, search, or link to the full texts of articles. This journal is covered under the CC BY-NC-ND license. 


\title{
PURDUE
}

UNIVERSITY PRESS <http://www.thepress. purdue.edu>

\section{CLCWeb: Comparative Literature and Culture}

ISSN 1481-4374 <http://docs.lib.purdue.edu/clcweb> Purdue University Press @Purdue University

CLCWeb: Comparative Literature and Culture, the peer-reviewed, full-text, and open-access learned journal in the humanities and social sciences, publishes new scholarship following tenets of the discipline of comparative literature and the field of cultural studies designated as "comparative cultural studies." In addition to the publication of articles, the journal publishes review articles of scholarly books and publishes research material in its Library Series. Publications in the journal are indexed in the Annual Bibliography of English Language and Literature (Chadwyck-Healey), the Arts and Humanities Citation Index (Thomson Reuters ISI), the Humanities Index (Wilson), Humanities International Complete (EBSCO), the International Bibliography of the Modern Language Association of America, Comparative Cultural Studies. Contact: <clcweb@purdue.edu>

\author{
Volume 19 Issue 5 (December 2017) Article 11 \\ Yi Wan, \\ "The Significance of the Variation Theory in Cross-Cultural Communication" \\ <http://docs.lib.purdue.edu/clcweb/vol19/iss5/11> \\ Contents of CLCWeb: Comparative Literature and Culture 19.5 (2017) \\ Special Issue Against the "Death" of the Discipline of Comparative Literature of Literature \\ Ed. Shunqing Cao \\ <http://docs.lib.purdue.edu/clcweb/vol19/iss5/>
}

\begin{abstract}
In her article "The Significance of the Variation Theory in Cross-Cultural Communication" Yi Wan analyzes some problems that East-West Comparative Literature, as a discipline, has encountered and discusses the significance of the development of the Variation Theory, proposed by Shunqing Cao. The author aims to explore two important points of this new platform, namely, heterogeneity and variation, and compares this new perspective to the French School, which is based on "influences" and the American School which is based on "analogies." By investigating the variations of literary texts or theories during the course of cross-civilization communication from the perspectives of imagology of Variation Theory and sinicization of western literary theory, this article posits that more attention should be given to this new paradigm of comparative literature studies. Variation Theory is based on maintaining and developing the uniqueness of different literature and cultures. It strives to see literature in the light of the culture it was created in, free of the paradigms of the culture it is being shared with.
\end{abstract}




\section{Yi WAN}

\section{The Significance of the Variation Theory in Cross-Cultural Communication}

Comparative Literature, as a discipline, has been difficult to define since its birth. Questions have been raised about the name, nature, identity, and methodology of comparative literature from its beginning. As Herbert Weisinger and Georges Joyaux's translation of René Etiemble's, The Crisis in Comparative Literature, has stated, there has been scant consensus about the conception and purpose of the field from its very inception. Every generation of scholars in the field has wrestled with various "crises," some internal to the discipline, some external. The nature and direction of comparative literature has become a heated question since the publication of Comparative Literature in the Age of Multiculturalism in 1955. About half a century later, in 2006, Pauline Yu traced the history of "comparative literature in question" and pointed out that "in comparative literature's history, then, we can witness a series of contests that have shaped the past two centuries, between nationalism and cosmopolitanism, scientism and humanism, literature and theory, and within the very notion of disciplinarity itself" ("Comparative Literature"38). Yu gave a detailed overview of how the history of debate lasted in the field of comparative literature for nearly two centuries. In regards to the globalizing perspective of the new tendency of comparative studies, she urged scholars to "constantly take care to ensure that a new cosmopolitanism does not disguise a much older form of metropolitan thinking"("Comparative Literature" 52). She then took the East-West comparative literature as an instance to interpret it in detail. What Yu emphasized is as follows:

For instance, when the field of 'East-West comparative literature' first opened up to introduce consideration of Asian examples, comparisons were inevitably one-sided or unwittingly invidious: similarities or 'affinities' could be demonstrated if something Chinese was just like something European. Discussions comparing Chinese to Western poets on an individual basis proliferated, uncovering the proleptically 'romantic' or 'symbolist' practices of the former, or discovering that deconstruction's heralds were fourth-century B.C.E. Daoists. If differences existed, it was to the detriment of the Chinese example (China 'lacked' epic and tragedy, for example, or its fiction suffered from the 'limitations' of a strong didactic impulse). Entire richly varied traditions became homogenized as unqualified monoliths in the face-off of East and West, with a selected group of Asian texts and figures charged with the burden of being 'representative,' reduced to distillations of an already essentialized culture, and subject to the measure of literary 'universals' that turned out, to no one's surprise, to be Western ones" ("Comparative Literature" 52).

An interesting focus for academia has been how to avoid a "highly normative procedure" in the study of East-west comparative literature, which Natalie Melas once warned against.

In 2003, James St. André wrote a review article, "Whither East-West Comparative Literature? Two Recent Answers from the U.S." (291) in response to Cai Zongqi's, Configurations of Comparative Poetics: Three Perspectives on Western and Chinese Literary Criticism (2002), and Haun Saussy's, Great Walls of Discourse and Other Adventures in Cultural China (2001), "both of which have something to say about where the field might move" (André, "Two Recent Answers" 292). This article presents the background and reasons for the rise of East-West comparative studies in the United States in the 90 s. It points to that the challenges from rival disciplines (cultural studies, translation studies, and English), the rise of multiculturalism, and the wake of post-colonialism "has entailed expanding the discipline beyond the boundaries of Europe and the Americas, and emphasizing difference (or différence if you're a Derridean) rather than universality" (André,"Two Recent Answers" 292). The article also mentions the emergence of a "Chinese" school of Comparative Literature, especially the methodology it takes: the application of Western theory to Chinese texts, and reveals the methodological problems of the school. As far as Cai's works is concerned, André found that Cai "was forced to make frequent and sweeping generalizations about 'China' and 'The West.' This leads to a reification of these two entities and a dangerous tendency to reductionism, which Pauline $\mathrm{Yu}$ and, more recently, Zhang Longxi (Mighty Opposites) have critiqued" (André,"Two Recent Answers" 295). The criticism is based on the major concepts discussed in the first half of Cai's book which leads to a neat development of two traditions, far from the real and whole picture of "China" and the "West." In other words, there are some thinkers and poetic works of "China" and the "West" being swept from Cai's scheme because they don't fit nicely into this scheme. Although André did not mean to disprove Cai's methodology and assertion by a few exceptions, he reminded us of Yu's warning from 1988: "Significant difference[s] over time and space evaporate in the hypostasis of forms and genres: all Chinese poetry is presented as concrete, mystical, personal, impersonal, static, cinematic, or whatever. And finally, entire richly varied traditions become unqualified monoliths in the face-off of 'East-West' Comparative Literature" (Yu, 
"Comparative Literature" 52). Yu's warning is still true even today. The 2000 years of poetics of "China" and the "West" cannot be summed up in a static structure or one word, "truth" or "harmony". In terms of Cai's methodological proposal in the field of East-West comparison in his epilogue, André has a few reservations and he gives reasons in detail. Among those reasons the significant one is that he does not think cultures are separate, independent entities, so Cai must reify China and the West before he does his comparisons. André's critique is sound because there are not two separate, independent and static systems of traditions. The engagement between Chinese and Western culture has been a valuable subject in terms of East-West Comparative Literature. Since the two cultures are dynamic systems, what will happen when they meet? Haun Saussy's, Great Walls of Discourse and Other Advantages in Cultural China (2001), gives a quite depressing answer: "one side or the other has misread its 'Other' in the mirror of the self, putting that 'Other' to use in its own best interests"(Saussy, Great Walls 289). What impresses André most is the methodology taken in the fourth and fifth chapters of Saussy's work, which "is a welcome and salutary path, one which might help to avoid the 'polemical comparison' which Cai warns against" (André, "Two Answers" 301). With some examples and vignettes of past interactions between these two cultures Saussy eschews the type of similarity/difference comparisons that Cai pursues, preferring instead to look at the interaction of the two cultures. In the concluding part of his article, André advocates a "middle way" or a "third party" to look for reciprocity rather than antithesis (André, "Two Answers" 301). He also explains that the academia of comparative literature must meet the challenge posed to it by literatures outside of the EuroAmerican system, otherwise this discipline will, as Susan Bassnett argues, die. He draws a conclusion that, "the question of how to proceed in East-West studies is thus a vital one for the entire field"(André, "Two Answers" 302). Fortunately, with the growth of East-West comparative literature in East Asia, another Chinese School of comparative literature proposed a new answer to it. Cao Shunqing's, The Variation Theory of Comparative Literature, can be regarded as a recent answer from China to the question "Whither East-West comparative literature". Cao advocated that a "middle way" or a "Third party" is to look for reciprocity rather than antithesis.

Two keywords are worth noting in particular about this new platform: heterogeneity and variation. Cao's variation theory concentrates on the heterogeneity of both literature and the concepts of literary studies within the homogenous tradition, Eastern or Western. The heterogeneity of literature, in other words, is the individuality and characteristics of national literature. Cao insistently maintains a focus on the heterogeneity of different civilizations and he addresses that "the notion of 'comparison' should not be used to blindly deny the heterogeneity among civilizations" (Cao, Variation Theory 229). His aim is "to rethink the theoretical framework of Comparative Literature and to re-illustrate the issue of 'comparability'" (Cao, Variation Theory 229). Based on this, he draws a conclusion that "the research mode of the comparability based on the concept of seeking for 'sameness' while putting aside differences should be abandoned; the researching model of seeking for heterogeneity and irrelevance among civilizations should be adopted...This is the basic idea of Variation of Comparative Literature and also a major theoretical breakthrough at the current stage of development" (Cao, Variation Theory 229-30).

This "theoretical breakthrough" is an invitation for any scholar to enter into a dialogue with the "otherness" of different literature and civilizations, try to understand the discourses, concepts and logic of "other" systems of thoughts, and "to pay more attention to the literatures and the traditions of literary studies of non-Western sources before they are adapted or translated- in the widest sense of term- to Westernized discourses, and genres, communicative strategies, and so on"(Larsen, "Review" 437-38). It is a significant breakthrough to the academia of comparative literature for the reason that Cao presents his ideas on the encounter of East and West beyond an orientalist and post-colonial perspective. This is based on the assumption that literature is constituted by the exchange of ideas across civilizations, and we must respect the heterogeneity of different civilizations, so that the individuality and uniqueness of civilizations and literature can be interpreted and understood. This is the starting point to begin the variation study in East-West comparative literature with the aim of communication and complementation among national literatures. If the heterogeneity of cross-civilization literature can't be clearly explored, it is likely to lead to the decline and loss of uniqueness. Cao demonstrates this with a series of examples, and Chinese literary theory is one of what he is concerned about most.

In line with the focus of heterogeneity, Cao emphasizes the variation of literature and means to turn comparison into a study of variations. Cao describes the definition of variation as the following: "According to the Variation of Comparative Literature, the transcendence and literary qualities of Comparative Literature are considered the foundation for research. Based on this, the variations of the literary phenomena are studied, and literary heterogeneity and variability of non-factual related liter- 
ary phenomena are also studied, through which the inherent principles of the differences and variations of literary phenomena are explored and illustrated" (Cao, Variation Theory 230). According to his description, we find that Cao is not only concerned with the heterogeneity and variability of literary phenomena, but he also pays attention to "the Variation of the exchanges of the literary phenomena," which is a kind of cross-civilization dynamic that generates literary phenomenon, its effects, and its conceptualization (Ibid). In other words, variation refers to the evolution and change of a literary text during the course of cross-civilization communication, especially in the process of literary criticism and study. After being translated, interpreted, and criticized by different individuals, the content of a literary work may evolve and become quite different from the original. This process is also called interlanguage practice, or variation. A study of variations deserves more attention from the present comparatists.

Cao's theory about heterogeneity and variation has been actualized in his studies over a number of years for the Chinese research community in a series of talks and papers. By examining the evolution of literary texts traveling cross boundaries, Cao aims to find out the intrinsic regularity of variation. He categorizes the variation study into translatology, imagology, receptionology, thematology, genology, and literature misreading and cultural filtering. Compared to French comparatism, which is based on "influences," and American scholarship, based on "analogies," Cao's variation study pays more attention to heterogeneity and variability.

Given that Cao's variation theory is open to any cross-civilization dialogue and is an invitation to communicate, this essay tries to do a serious investigation into the imagology study of variation theory and sinicization of western literary theory proposed by Cao, and attempts to illustrate how the variation happens from these two perspectives.

French imagologists, according to Jean-Marc Moura, are concerned with "image" which is a triple sense of an image, that is, first, it is the image of the exotic ("image d'un référent étranger"), which analyses descriptions of the Other as historical documents; second, it is from a nation, society, culture ("image provenant d'une nation ou d'une culture") that the image draws an entire complex of social and cultural attitudes into literary analysis; third, the image is formed from a writer's special sense ("image créée par la sensibilité particulière d'un auteur"), which examines the personal myths of authors in the light of the imaginary horizon of a particular period. (Moura, "Literary Imagology" 271-87, English translations are mine). David Hume believes that images, presented by the senses are nothing but representations of "the Other," or represented image, whereas Jean Paul Sartre holds that images are the present Other's imagination of the absence, or recreated image. Their opinions are the inverse of each other, the former advocating "represented image" while the latter "recreated image". Hume regards images of other existences as copies or representations sensed by a certain author. Sartre takes images as the authors' creation, far different from the original perception. The distinct difference between them is whether the image is similar to the real one or not.

First, according to Moura's definition of image, we know that the image of the Other country examined by French imagologists is just an illusion created by authors according to their personal perception, not a close representation of their living experience in that country. When describing the other nation, authors read and perceive the Other via literary texts of their own community. In other words, authors write, not according to their own experience, but in line with their society's collective imagination of the Other. Therefore, the image studied by the French imagologists is a created one, similar to that of Sartre's.

Second, French imagologists are reluctant to perceive the other nation's image from foreigners' living experiences. What they are concerned with tracing the stereotyped image ethnocentrically created by their collective imagination. According to contemporary French philosopher Paul Ricoeur book From Text to Action (1991), images of the Other can be stratified into ideological imagination and utopian imagination. Ideological imagination parrots the local literature's description of the Other, whereas utopian imagination is simply an independently created process, which ignores the local collective imagination. The former refers to image, which is a depiction, or presentation, of the viewers' social order and discourse. The latter appears as eccentric and erratic, delineating self-contained schemas of the Other.

Therefore, ideology has one fundamental function: to mediate and integrate a community, society or culture according to its real basis. Ideology has three layers: distortion, legitimation, and symbolization. Under the layer of distorting representation is the layer of the systems of legitimation which legitimate the given system of authority. Under the layer of legitimation are the symbolic systems constitutive of action itself. By this way, the real basis represents and reinforces itself by dissimulating and distorting the Other. In fact, ideological images of the Other reflect the basic view of value of the 
given ethnic group. Conversely, the utopia has a subversive function, which admits the heterogeneity of other civilizations.

From the above, we could draw a conclusion that the French school concentrates on the relationship between the image and the integral imagination of the society. The integral imagination of the society is related to the following factors. First, it is the public opinion. Second, it is the spiritual life. Third, it is the foreign affairs. Fourth, it is literature and non-literature. Fifth, it is all kinds of symbols.

The integral imagination of the society has huge influence on the writer's works, however, the main goal of the French school, today, is to focus on the integral imagination of the society. The integral imagination, in essence, is imagination, which cannot be illustrated in concrete proofs. What we could illustrate is to describe the influence of the media and literary works on the writers' works at most. That's why we say the image study beyond the theory of the French school. To some degree, we may say that it belongs to the variation study because what the scholars of French school concentrate on is the integral imagination of the society. Furthermore, the image is not the country's reproduction itself and distinct difference between them exists. The study of image has gone beyond the range of the French school.

The variation study focuses on the variation that emerges from in the process of the intercultural communication. The image of one country changes during the course of works traveling from one land to another with the rewriting in literary works. Because of different cultures, psychological, theological, and historical contexts, the image of one country changes, and difference occurs without doubt. The transformation of the image of one country is inevitable and is what the variation study emphasizes. Moreover, variation study concerns the difference of culture during the course of intercultural communication. The rule of heterogeneous culture is also what we concentrate on. That is the value of variation study. On this ground, variation study provides a new point of view and a new way to define Comparative Literature.

The imagology of French school is regarded as the research of the imagination of the Other. It is related to the literary history of culture and international relationships. However, as a matter of fact, the change is the focus of the variation study. The French school does research on the imagination with concrete proof. That is a contradiction. Thus the topic of imagination should belong to the variation study.

Image in variation study is related to creative imagination. Image is not something reappearing. In other words, the image in variation study is a mixture of subject, object, and a combination of feelings and thoughts. The objective image has been transformed and remolded by the writers through the intercultural travel. As a matter of fact, the historic and cultural reality has been transformed on homology, and the variation study emphasizes the variability.

In addition, the issue of "other country's image" has already been included by the French school, whose essence is the study of the variation of images. Therefore, the French school has touched upon the study of variation without being aware of it, not to speak of making various theoretical assumptions.

We can say that early studies of images have already exceeded the scope of positivistic research of the French School. The most typical examples are the studies made by Jean-Marie Carré and MariusFrancois Guyard. Carré published French Writers and the German Mirage: 1800-1940 (Les écrivains français et le mirage allemand: 1800-1940) in 1947, and Guyard's Comparative Literature (La littérature Compare 1983) was the first theoretical study of images. In the book, Guyard included a chapter "Other Countries in Our Eyes" (Guyard, Comparative Literature 152) to discuss the issues of images. Actually, Guyard and Carré started a new direction for research- Imagology. Although the non-positivism of Imagology is not admitted by them, it is obvious that it cannot be carried out with only positivistic methods. In fact, the French school is engaged in non-positivistic studies with the socalled scientific methods. So Imagology studies should not be classified into influence studies of the French school.

In fact, Imagology should be classified into the scope of the study of variations. Its object is to explore the Other country's image in different national literatures. Since the Other country's images are a kind of "national illusion," which can only be a thing of variation instead of being positivistic fact. For example, Chinese people used to call foreigners as "Yang Ren"(people from overseas), and call the Japanese as "Guizi"(japs), which are the nationwide illusions of Chinese people towards foreigners and Japanese. As Imagology is related to factors of illusions, it is bound to generate misconceptions. From the perspective of variation, the illusions of the image has also undergone a fundamental change, that is, from the "reproductive imagination" up to "creative imagination", which is a blend of reproduction both subjective and objective, both emotional and rational. The image of "otherness", which has un- 
dergone a series of reproduction and recreation, is certain to be changed. It is impossible to apply the scientific and positivistic methods to the research on the complex process of variation.

Sinicization of western literary theories is one of the important aspects in variation studies. In Cao's works, he explains variability; that new things will be inevitably brought into being when literary works disseminate from one country to another(Cao, Variation Theory 229) In other words, when western ideas and theories travel to China, changes have taken place during the course of the intercultural communication. New things are inescapable. The framework may still be western, but there must have been certain variations and deviations in the cultural transmission, as the original culture, when being transplanted into another, will face the process of being selected, filtered, reinterpreted, and adapted.

Edward W. Said states in his Traveling Theory (1983) that ideas and theories travel like peoplefrom person to person, from situation to situation, and from one period to another. One should go on to specify the kinds of movement that are possible, in order to ask whether by virtue of having moved from one place and time to another an idea or a theory gains or loss in strength, and whether a theory in one historical period and national culture becomes altogether different for another period or situation. There are some particularly interesting cases of ideas and theories that move from one culture to another, as when certain European ideas on society were translated into the traditional Eastern societies during the late 19th century. It specifically involves processes of representation and institutionalization different from those at the point of origin. There is, however, a discernible and recurrent pattern to the movement itself, three or four stages common to the way any theory or idea travels. First, there is a point of origin, or what seems like one, a set of initial circumstances in which the idea came to be or entered discourse. Second, there is a distance traveled, a passage through the pressure of various contexts as the idea moves from an earlier point to another time and place. Third, there is a set of conditions- call them conditions of acceptance or, as an inevitable part of acceptance, resistance- which then confronts the transplanted theory or idea, making possible its introduction or toleration, however alien it might appear to be. Fourth, the now full (or partly) accommodated (or incorporated) idea is to some extent transformed by its new uses, its new position in a new time and place.

When an idea or a theory is introduced into a new context, it is apt to either gain or lose in strength. From the point of the variation studies, variability is an inevitable outcome when ideas and theories travel- from person to person, from situation to situation, and from one period to another. The change of strength, or how the variation occurs, is what the scholars should be concerned about. The scholars should concentrate on the interpretation of one theory in a different country and culture, but it's not appropriate to simply use the word "misunderstanding" to judge any interpretation of the theory because it is very likely that the critics' responsibility will be improperly ignored in this way. The main task for the scholars is to make it clearly known how the changes and misinterpretation occur. That is, the major objective of the variation studies is to find out how the alien elements of the theory are adapted in the course of intercultural communication, how the limitations of the theory are avoided in a new cultural context, and how the theory collides with, and finally blends into, the target culture. As a matter of fact, the theory would be over-simplified, institutionalized, or even become a trap in the end, if it is used for many times without analyzing its heterogeneity and variability.

Furthermore, one theory is always open to the future. It can never be finished in some sense, just like a person with endless interests. In addition, it's also fun for people to interpret a theory with new examples. It is absurd for some people to reject theories just because they think that great works can be appreciated as well without the aid of any theory.

Take body narrative theory for example. The theory emphasizes women should depict themselves and reflect their voice in the texts, so that they can cast off the conventional ideas, especially patriarchy, and defend their own rights. The theory, raised in the context of the Feminism Movement in the western world, puts forward that female writing should become an absolutely necessary part of the world's history. It can be seen that the theory was put forward in the context of overturning the patriarchy and constructing a new aesthetic sphere. However, changes have occurred to the theory when it travels from the West to China to enter a quite different context blending traditional Chinese concepts with the post-modern consuming culture. The human body, unlike in the Western culture, is an issue to be neglected and avoided in traditional Chinese culture. It's somewhat oppressed and looked down upon in Confucianism, Buddhism, and Taoism (He 89-92). Professor Xie Youshun states in his thesis that Chinese people in ancient times inclined to avoid the topic of the human body, which was taken as a taboo in the long history of Chinese culture. He also points out that the human body is regarded as a breeding ground for crimes in ancient China (Xie 30-34). The traditional concept still has great influences on people in the contemporary era. From the perspective of variation studies, variability 
occurred after the theory entered China. The idea of the post-modern consumer culture, which originated in the Western society, could hardly find the proper context for its former interpretation in China. The Chinese people, who seemed to accept the idea of post-modern consumer culture, were still restrained by the traditional concept about the female body. In addition, the consumer environment also exerted great effects on people, especially some female writers who began to describe women's bodies and sexual life in their books with goal of catering to men's lust. As a result, the significant revolutionary implications of the body narrative theory was simplified and interpreted as a pure physical enjoyment of sex. This finally leads to a kind of false body narrative (Ibid).

In conclusion, the academia must be aware of the variability of an idea or a theory when it travels from one place to another place, one period to another period, one person to another person, and one context to another context. For another example, there are great differences between the French Realism and the English Realism in the 19th century, since they were nurtured in different cultural contexts. When the French Realism was introduced into China, there were substantial variations and deviations. It's impossible that the transplanted French Realism is still the same as that in France, nor could we define the cultural context in France in the 19th century from the adaptation. Chinese critics must pay great attention to the differences between the original theory and the interpreted theory in a new context. That means, the duty of Chinese critics is to explore the variability of a source theory in Chinese literature and culture, so that it can be useful in a new context.

In Professor John Fiske's book, Understanding Popular Culture, he presents a radically different theory of what it means for culture to be popular. It is not imposed on them, it is created by them, and its pleasures and meanings reflect popular tastes and concerns and a rejection of those fostered by mass culture. Rather than focusing on mass culture's attempts to dominate and homogenize, he prefers to look at and revel in popular culture's evasions and manipulations of these attempts. With wit, clarity, and insight, Fiske debunks the myth of the mindless mass audience, and demonstrates that, in myriad ways, popular culture thrives because that audience is more aware than anyone guesses. When his theory traveled to China, Chinese scholars, based on the country's specific context in which its mass culture was shaped, concentrated on the studies of the active role its people played in outputting cultural products. Variation study concerns the gains and losses of one theory's strength when it travels and the gap between the original theory and the interpreted theory in a new context.

Although the French school proposed "influence studies," and the American school proposed "analogy studies," it is still obvious to us that the whole theoretical system of Comparative Literature is far from complete. As a new perspective and method, the proposal of Variation Theory of Comparative Literature will be a major breakthrough. It opens a new stage in the course of the development of East-West comparative literature-the research focusing on heterogeneity and variation. This theory not only highlights the differences among various civilizations, but also promotes dialogues and exchanges of civilizations, making a new era of human history of literature.

From the homogeneity to heterogeneity to variation, the theoretical exploration goes deeper and further. Variation Theory is not only the most valuable branch of Comparative Literature but an innovative approach to study the whole human culture.

Note: I thank Shunqing Cao, Greg Smith and the two anonymous reviewers for their comments. Research for this article has been funded by Chinese Scholarship Council (CSC) under the project "The Variations of Chinese Literature in English-Spoken World" and by the Sichuan Social Science Foundation under the project "Study on Poetry of Sung Dynasty in the Sinology of North-America"(北美汉学界的宋诗研究).

\section{Works Cited}

André, James St. "Whither East-West Comparative Literature? Two Recent Answers from the U.S." Journal of Chinese Literature and Philosophy Studies (中国文哲研究集刊), 22 (2003):291-302.

Cao, Shunqing (曹顺庆). The Study of Comparative Literature (比较文学学). Chengdu: Sichuan UP, 2005.

Cao, Shunqing (曹顺庆). Tutorial of the Chinese Comparative Literature (比较文学教程). Beijing: Higher Education P, 2006.

Cao, Shunqing (曹顺庆). "The Variation Study: Breakthrough in Theories of Comparative Literature" (变异学: 比较文 学学科理论的重大突破). Journal of Sun Yatsen University (Social Science Edition), 48.4 (2008): 28-36.

Cao, Shunqing (曹顺庆). The Variation Theory of Comparative Literature. Heidelberg: Springer, 2014.

Carré, Jean Marie. French Writers and the German Mirage:1800-1940 (Les écrivains français et le mirage allemand: 1800-1940). Paris: Boivin et Cie, 1947.

Eagleton, Terry. Literary Theory: An Introduction. Oxford: Blackwell Publishing Ltd, 2008.

Fokkema, Douwe. "Foreword." The Variation Theory of Comparative Literature. Cao, Shunqing. Heidelberg: Springer, 2013. 
Foucault, Michel. The Archaeology of Knowledge. Beijing: The Joint Publishing Company Ltd, 1998. Fiske, John. Understanding Popular Culture. Boston: Unwin Hyman, 1989.

Guyard, Marius-Frantçois. Comparative Literature (La Littérature Comparée). Trans. Yan,Bao (颜保). Beijing: Peking UP, 1983.

He, Ziwen (何字温). "An Introduction to Recent Researches on 'Feminist Body-Writing'" (近年文坛"身体写作"研究概观). Journal of Hainan Normal University (Social Sciences). 18.3 (2005): 89-92.

Huntington, Samuel P. The Clash of Civilizations and the remaking of World Order. New York: Simon \& Schuster, 1996.

Larsen, Svend Erik. "The Review of the Variation Theory of Comparative Literature." Orbis Litterarum 70.5 (2015): 437-438.

Moura, Jean-Marc. "Literary Imagology: A Trial of Historical and Critical Focus" (L'imagologie Littérature: Essai de mise au point historique et critique). Comparative Literature Review (Revue de literature comparée. 3 (1992): 271-287.

Qian, Zhongshu (钱锤书). Art Dialogue (谈艺录). Beijing: Zhonghua Book Company, 1984.

Ricoeur, Paul. From Text to Action. Evanston: Northwestern UP, 1991.

Stallknecht, Newton P. and Frenz Horst, eds. Comparative Literature: Method and Perspective, Carbondale: Southern Illinois P, 1971.

Said, Edward W. "Traveling Theory." The World, the Text, and the Critic. Cambridge: Harvard UP, 1983.

Said, Edward W. Orientalism. New York: Random House, 1978.

Tu, Weiming (杜维明). Clash of Civilizations and Dialogue (文明的冲突与对话). Ed. Zhu Hanmin (朱汉民) and Xiao Yongming (肖永明). Changsha: Hunan UP, 2001.

Tu, Weiming (杜维明). "The Context of Dialogue: Globalization and Diversity" (文明对话的语境: 全球化与多样性).

Ed. Tu, Weiming (杜维明) and Liu Debin (刘德斌). Collected Papers of History Studies (史学集刊)，18.1 (2002)：1-13.

Wellek, René. "The Crisis of Comparative Literature." Proceedings of the Second Congress of the International Comparative Literature Association, University of North Carolina Studies in Comparative Literature. Ed. Friederich Werner. no. 23. Chapel Hill: U of North Carolina P, 1959.

Wang, Ning (王宁). "Variation Theory and Comparative Literature: A Book Review Article about Cao's Work." Comparative Literature and Culture. 15.6 (2013): 18-19.

$<$ http://docs.lib.purdue.edu/cgi/viewcontent.cgi?article $=2371 \&$ context $=$ clcweb $>$.

Xie, Tianzhen (谢天振). Medio-Translatology (译介学). Shanghai: Shanghai Foreign Language Education Publishing House, 1999.

Xie, Youshun (谢有顺). "The Study of Body Narrative" (身体叙事研究). Ed. Wang, Ming-an (汪民安). On cultural Politics of Body (身体的文化政治学). Kaifeng: Henan UP, 2003.

Xie, Youshun (谢有顺). "On Body Ethics of literary Narrative" (文学叙事中的 "身体伦理"). On Novels Review (小说评论). 2 (2006): 30-34.

Xiao, Shuai (肖帅). "On the Variation of John Fiske's Theory of Popular Culture in China" (积极能动的大众一一约翰·费 斯克大众文化理论的中国变异). Ed. Cao, Shunqing (曹顺庆) Culture and Literary Theory (中外文化与文论). Chengdu: Sichuan UP, 20.1 (2011): 45-50.

Yu, Pauline. "Comparative Literature in Question." Daedalus. 135.2 (2006): 38-53.

Yu, Pauline. "Alienation Effects: Comparative Literature and the Chinese Tradition". The Comparative Perspective on Literature: Approaches to Theory and Practice. Ed. Koelb, Clayton and Noakes, Susan. Ithaca: Cornell UP 1988.

Zhang, Longxi (张隆溪). Opposites: From Dichotomies to Differences in the Comparative Study of China. Stanford: Stanford UP, 1998

Zhang, Longxi (张隆溪). Mighty Opposites: From Dichotomies to Differences in the Comparative Study of China. Stanford: Stanford UP, 1998.

Zhang, Longxi (张隆溪). "The Challenge of East-West Comparative Literature." China in a Polycentric World: Essays in Chinese Comparative Literature. Stanford: Stanford UP, 2005.

Author's profile: Yi Wan (万焱) teaches Comparative Literature at the School of Humanity at the Sichuan University of Science and Engineering. Her interests in scholarship include Comparative Literature, inter-cultural studies and translation studies. Wan's publications include: "跨文明语境下的比较文学变异学" ("The Variation Theory of Comparative Literature in the Cross-Civilization Context"), Journal of Inner Mongolia Social Sciences (2013)，"中美'苏学'学术 话语与理论视角比较研究" (Comparative Study on Discourses and Perspectives of Chinese and American researches on Sushi), English Studies (2017). E-mail: <wan.286@osu.edu> 